\title{
Hambatan belajar matematika di pondok pesantren
}

\author{
Sendi Ramdhani', Didi Suryadi² dan Sufyani Prabawanto 3 \\ ${ }^{1}$ Pendidikan Matematika, FKIP, Universitas Suryakancana, Jl. Pasirgede Raya, \\ Kabupaten Cianjur \\ 2,3Universitas Pendidikan Indonesia, Jl. Dr. Setiabudi, Kota Bandung \\ *sendi@unsur.ac.id
}

Received: 03 November 2020; Accepted: o9 Juni 2021 ; Published: 30 Juni 2021

\begin{abstract}
Abstrak
Penelitian ini bertujuan untuk mengidentifikasi hambatan belajar yang dialami santri dalam proses pembelajaran matematika di pondok pesantren. Kajian interpretatif digunakan untuk mengidentifikasi hambatan belajar yang dialami santri dalam proses pembelajaran matematika di pondok pesantren. Tujuan utama kajian interpretatif ini adalah memahami secara mendalam suatu realitas yang berbasis filosofi fenomenologis. Terdapat beberapa hambatan belajar yang dialami santri dalam pembelajaran matematika di pondok pesantren, yaitu: 1) Hambatan ontogenik yang dialami santri berasal hambatan ontogenik instrumental dan hambatan ontogenik konseptual sehingga berpengaruh terhadap hambatan ontogenik psikologis, yaitu membuat motivasi dan ketertarikan santri terhadap pembelajaran matematika menjadi menurun; 2) Hambatan didaktik terjadi karena kurikulum matematika yang digunakan sama dengan kurikulum matematika di SMA atau MA sehingga berpengaruh terhadap penyajian dan pengajaran matematika oleh guru di kelas karena mengejar materi yang banyak sedangkan jam pelajaran yang terbatas jadi tidak dapat memaksimalkan proses pembelajaran matematika dan mengakomodir peningkatan kemampuan santri yang terkait dengan kebutuhan mereka sebagai kader ulama, termasuk dalam meningkatkan kemampuan berfikir; 3) Hambatan epistemologis terjadi karena proses pembelajaran terpaku kepada buku teks SMA atau MA sehingga konteks pembelajaran sama dengan pembelajaran matematika di SMA atau MA dan tidak dikaitkan dengan konteks pengetahuan agama Islam atau sesuai dengan situasi (muqtadhal hal) pondok pesantren setempat.
\end{abstract}

Kata kunci: Hambatan Didaktik, Hambatan Epistemologi, Hambatan Ontogenik, Learning Obstacle, Santri

\begin{abstract}
This study aims to identify learning obstacles experienced by santri (students) in mathematics learning process in Pesantren (Islamic Boarding School). Interpretive studies are used to identify learning obtstacles. There are several learning obstacles experienced by santri in mathematics learning in Pesantren: 1) The ontogenic obstacles experienced by santri come from instrumental ontogenic and conceptual ontogenic, which affect psychological ontogenic (motivation and interest); 2) Didactic obstacles occur because the mathematics curriculum used is the same as the mathematics curriculum in SMA or MA. They pursue a lot of material while the lesson hours are limited so they cannot maximize the mathematics learning process and accomodate santri abilities with their needs as a cadre of ulama; 3) Epistemological obstacles occur because the learning process is fixated on SMA or MA textbooks so that the learning context is not linked to the context of Islamic religious knowledge or adapted the situation of Pesantren.
\end{abstract}

Keywords: Didactic Obstacles, Epistemological Obstacles, Islamic Boarding School, Learning Obstacles, Ontogenic Obstacles 


\section{PENDAHULUAN}

Pondok pesantren merupakan lembaga pendidikan Islam yang memiliki akar sejarah yang kuat di Indonesia karena merupakan lembaga pendidikan Islam tertua di Indonesia yang tumbuh bersamaan dengan masa penyiaran Agama Islam (Pontren, 2009) . Pondok pesantren adalah lembaga yang bisa dikatakan merupakan wujud proses wajar perkembangan sistem pendidikan nasional dimana dari segi historis pesantren tidak hanya identik dengan makna keislaman, tetapi juga mengandung makna keaslian Indonesia (Madjid, 1997). Pondok pesantren memberikan pendidikan dan pengajaran untuk mempelajari, memahami, menghayati dan mengamalkan ajaran Islam(Dhofier, 1982; Mastuhu, 1994; Nasir \& Abdushomad, 2005).

Fungsi utama pesantren adalah menyiapkan santri untuk mendalami dan menguasai ilmu agama Islam atau lebih dikenal Tafaqquh fi aldin, yang diharapkan dapat mencetak kaderkader ulama dan turut mencerdaskan masyarakat Indonesia dan melakukan dakwah menyebarkan agama Islam serta benteng pertahanan umat dalam bidang akhlak (Usman, 2013). Pondok pesantren terus berperan dalam mencerdaskan kehidupan bangsa (Tafaqquh fi al-din) dan memberikan pelayanan sosial (dakwah bil hal) dalam menyiapkan tenaga-tenaga yang menguasai ilmu-ilmu keislaman sebagai kader ulama, muballigh atau Guru Agama yang sangat dibutuhkan oleh masyarakat (Pontren, 2009).

Santri di pondok pesantren mempelajari Tafsir Qur'an, Hadits, Ilmu Tafsir, Ilmu Hadits, Tauhid, Akhlak/Tasawuf, Bahasa Arab/Ilmu Alat, Nahwu Shorof, Fiqh, Ushul Fiqh, dan lain-lain untuk mempersiapkan diri menjadi kader ulama. Adapun ulama menurut Syekh Nawawi Al-Bantani(Hsubky, 1995) adalah orang-orang yang menguasai segala hukum syara' untuk menetapkan sah itikad maupun amal syariah lainnya. Sedangkan menurut Ain Najaf, salah satu tugas ulama adalah mengembangkan berbagai pemikiran sebagai rujukan umat dan mengeluarkan fatwa tentang berbagai hal yang berkenaan dengan hukumhukum Islam (Eksan, 2000). Ifta' (pekerjaan memberi fatwa) adalah sinonim dari ijtihad (Arifin, 2015). Ijtihad adalah melakukan usaha keras atau pengerahan segenap kemampuan mujtahid (orang yang melakukan ijtihad) dalam mencari atau menggali pengetahuan mengenai hukum syariat (Zaidan, 1990).

Seorang mujtahid harus memiliki pengetahuan Agama Islam antara lain mengetahui $\mathrm{Al}-$ Qur'an, As-Sunnah, ijma (konsesus ulama), dalil-dalil dengan segala persyaratannya, bahasa arab, ushul fiqih, nasikh dan mansukh, hadits shahih dan bukan shahih, maksud syariah juga (Al-Syatibi \& Ishaq, 2003). Selain memiliki memiliki pengetahuan yang luas berkaitan dengan Agama Islam tersebut, seorang mujtahid juga harus memiliki kemampuan akal (berpikir), menguasai logika, daya nalar yang kuat (Al-Syatibi \& Ishaq, 2003; Tamawa, 1972). Kemudian, Abu Zahran (t.th) dan Al Basyri (dalam (Kesgin, 2011)) mengungkapkan bahwa seorang mujtahid harus memiliki pengetahuan mendalam tentang aturan dan prosedur penalaran oleh analogis (qiyas) sehingga ia dapat menerapkan hukum kasus yang belum pernah terungkap dan terjadi sebelumnya.

Ulama selain harus menguasai ilmu-ilmu Agama Islam, juga harus memiliki kemampuan berpikir yang baik karena merupakan syarat melakukan ijtihad dan juga beberapa tipe argumentasi yang digunakan dalam hukum Islam. Kemampuan berpikir tersebut antara lain: deduksi, analogi, induksi, konklusi (Hallaq, 1985). Berdasarkan hal ini, santri yang dipersiapkan sebagai kader ulama, mubaligh, dan guru Agama Islam harus memiliki kemampuan berpikir yang baik. Kemampuan tersebut akan sangat berguna ketika mereka menjadi ulama, mubaligh, ataupun guru Agama Islam. Salah satu fungsi ulama adalah menjadi rujukan masyarakat dan pembimbing masyarakat (Eksan, 2000; Kahmad, 2006) maka akan menjadi berbahaya jika salah dalam menentukan hukum-hukum syariah. 
Kemampuan berpikir penting bagi kader ulama sebagaimana diungkapkan di atas. Mata pelajaran yang dapat dimanfaatkan untuk mengembangkan kemampuan berfikir adalah matematika(Hiebert, 1997). Berdasarkan Peraturan Menteri Agama (PMA) tahun 2014 matematika merupakan mata pelajaran yang harus ada pada kurikulum satuan pendidikan muadalah (pesantren yang disetarakan)(PMA, 2014). Oleh karena itu, mata pelajaran matematika dapat digunakan untuk mengembangkan kemampuan berfikir santri sebagai kader ulama.

Matematika merupakan pelajaran yang penting diajarkan di Pondok Pesantren sebagaimana uraian di atas, namun pembelajaran matematika di Pondok Pesantren adalah jam pelajaran matematika hanya dua jam pelajaran dalam seminggu. Matematika hanya dipelajari untuk memenuhi kewajiban saja dan belum diintegrasikan dengan pelajaran agama Islam. Kesenjangan perhatian yang terjadi pada mata pelajaran matematika dan agama di Pondok Pesantren, sehingga berdampak santri pondok pesantren kesulitan memahami matematika. Hal ini tercermin dari hasil penelitian(Nisa, 2014) dan (Yusnita, 2011) yang mengungkapkan bahawa aktivitas santri dalam Pondok Pesantren selalu dikonsentrasikan kepada aktivitas yang berlandaskan kepada pendidikan agama yang merupakan rutinitas mereka, akibat dari kebiasaan tersebut, santri kurang tertarik mempelajari mata pelajaran umum seperti matematika.

Penelitian ini bertujuan untuk mengidentifikasi hambatan belajar yang dialami santri dalam pembelajaran matematika sehingga diharapkan memberikan wawasan tentang bagaimana seharusnya pembelajaran matematika di pondok pesantren. Hal ini sesuai dengan rekomendasi Balitbang Kementerian Agama RI perlunya segera dibuat pedoman penyusunan standar isi mata pelajaran pendidikan umum khas yang di dalamnya matematika bagi pondok pesantren yang berbeda dengan standar isi satuan lainnya (Balitbang, 2017).

\section{METODE}

Penelitian ini bertujuan untuk mengidentifikasi hambatan belajar yang dialami santri dalam proses pembelajaran matematika di pondok pesantren. Kajian interpretatif digunakan untuk mengidentifikasi hambatan belajar yang dialami santri dalam proses pembelajaran matematika di pondok pesantren. Tujuan utama kajian interpretatif ini adalah memahami secara mendalam suatu realitas yang berbasis filosofi fenomenologis (Suryadi, 2019). Deskripsi hambatan belajar ini dapat diperoleh melalui studi fenomenologi karena pertanyaan penelitian berkaitan dengan pengalaman para partisipan dan pengalaman tentang suatu konsep atau fenomena serta mengeksplorasinya (Liu, 2008). Adapun alur penelitian dijelaskan pada Gambar 1.

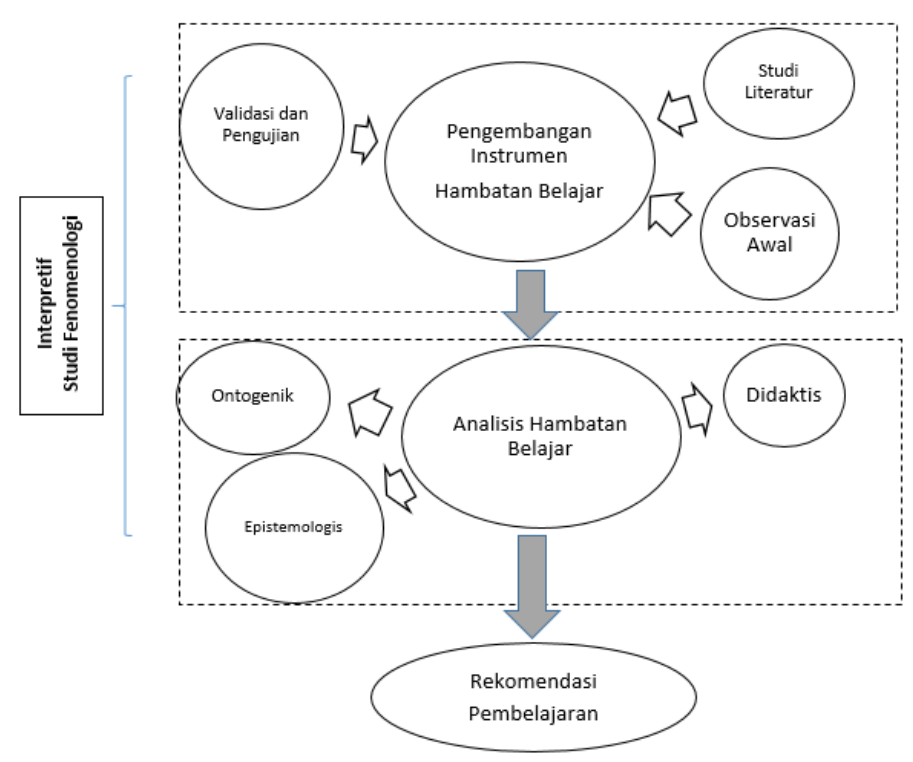

Gambar 1. Alur Penilitian

Subjek penelitian dalam penelitiaan ini adalah santri pondok pesantren muadalah. UndangUndang Republik Indonesia Nomor 18 Tahun 2019 Tentang Pesantren mengungkapkan bahwa Pendidikan Muadalah adalah pendidikan Pesantren yang diselenggarakan pada jalur pendidikan formal dengan mengembangkan kurikulum sesuai dengan 
kekhasan Pesantren dengan berbasis Kitab Kuning atau Dirasah Islamiah Dengan Pola Pendidikan Muallimin secara berjenjang dan terstruktur (Indonesia, 2019).

Subjek penelitian adalah 36 santri dari 4 Pondok Pesantren yang terdaftar sebagai penyelenggara Satuan Pendidikan Muadalah (SPM) 2019, dengan rincian 2 Pondok Pesantren di Kabupaten Bandung, 1 Pondok Pesantren di Kabupaten Garut, dan 1 Pondok Pesantren di Kabupaten Kuningan. Adapun Subjek penelitian untuk implementasi pengembangan desain pembelajaran adalah di kelas VI Tarbiyatul Mu'allimin wal Muallimat al Islamiyah (TMI) yang setara dengan kelas XII SMA di salah satu Pondok Pesantren Muadalah Kabupaten Bandung. Peneliti menganalisis beberapa jenis hambatan belajar.

1. Hambatan belajar ontogenik, yang terdiri dari:

a. Psikologis, yaitu motivasi dan ketertarikan yang rendah terhadap materi yang dipelajari.

b. Instrumental, yaitu kesulitan yang bersifat teknis yang disebabkan tidak paham akan hal kunci.

c. Konseptual, yaitu kesulitan yang bersifat tingkatan konseptual yang kurang sesuai dengan keadaan anak.

2. Hambatan belajar didaktis, yaitu hambatan belajar yang disebabkan faktor urutan dan atau tahapan penyajian.

3. Hambatan belajar epistemologis, yaitu keterbatasan suatu konteks yang digunakan pada saat pertama kali suatu konsep dipelajari.

\section{HASIL DAN PEMBAHASAN}

Mayoritas santri menganggap bahwa matematika itu penting dan sangat penting, walaupun ada santri yang menganggap bahwa matematika tidak terlalu penting bagi santri. Menurut beberapa santri matematika penting karena digunakan dalam kehidupan sehari-hari dan dibutuhkan dalam jenjang pendidikan tinggi.

Berikut ini adalah petikan ungkapan Azka.

Sangat penting untuk santri bahkan untuk semua orang apapun bidangnya, karena di dalam kehidupan dibutuhkan ilmu perhitungan/ hisab seperti dalam bidang jual beli. Matematika untuk bekal dalam kehidupan masa depan, untuk ilmu faraidh yang merupakan salah satu mata pelajaran di pondok kami.

Bandung, 19 Februari 2019

Kemudian menurut Nuri.

Penting sekali, karena dengan matematika kita bisa menghitung segala sesuatu dan bisa memprediksi dengan tepat dan tidak akan terkecoh.

Garut, 12 Maret 2019

Santri mengungkapkan bahwa beberapa kemampuan yang harus dilatih dalam pembelajaran matematika di Pondok Pesantren untuk mempersiapkan diri sebagai kader ulama, yaitu: ilmu faraidh (waris), pembagian zakat, menentukan bulan-bulan penting dalam Islam (Ramadhan), logika, berpikir, pengamatan, ketelitian, membuat dugaan, keberanian dalam mencoba, dan kesabaran. Menurut Restu pembelajaran penting untuk melatih santri sebagai kader ulama sebagaimana yang dia ungkapkan sebagai berikut.

Santri perlu dibekali dengan pembelajaran matematika dalam nenghitung zakat, menentukan jumlah warisan, dan akutansi masjid

Bandung, 20 Februari 2019 
Adapun menurut Syifa.

Kemampuan observasi, detail dan teliti dalam pengerjaan soal. Ketika menemukan masalah diobservasi dulu baru ditentukan hukumnya

Bandung, 19 Februari 2019

Hambatan dan kesulitan ketika belajar matematika menurut santri adalah mengantuk karena di pondok pesantren banyak kegiatan, pembelajaran matematika membosankan karena terlalu serius, materi dalam matematika sulit dipahami, rumus matematika rumit dan sulit dihafalkan, waktu pembelajaran matematika kurang, materi matematika terlalu banyak angka dan huruf, kurang percaya diri dalam menyelesasikan soal matematika, kesulitan dalam mengerjakan soal yang tidak sesuai contoh. Beberapa hambatan dan kesulitan tadi menurut santri mengakibatkan jadi malas belajar matematika, sebagaimana yang diungkapkan oleh Azka sebagai berikut.

Kurang paham atau kurang mengerti dikarenakan banyak hal, salah satunya adalah jam pelajaran yang sedikit, kurang sosialisasi dalam menerangkan atau kurang detail, banyak yang tidak mengetahui rumus dan cara yang mudah untuk mengisi soal sehingga kami kesulitan apabila menemukan soal yang rumit.

$$
\text { Bandung, } 19 \text { Februari } 2019
$$

\section{Adapun menurut Rizki.}

Terlalu banyak angka dan huruf, kurang latihan soal, sering lupa rumus, dan kurang percaya diri kalau dirinya bisa

$$
\text { Bandung, } 6 \text { Maret } 2019
$$

Kemudian menurut Haniefan.

Ngantuk, merasa bosan, dan terlalu banyak rumus

Kuningan, 16 April 2019
Motivasi guru dalam mengajarkan matematika antara lain:

1) Karena menyukai matematika dan ingin menyampaikan ilmu yang telah didapat kepada peserta didik

2) Membuat pembelajaran matematika lebih menyenangkan.

3) Meningkatkan logika peserta didik.

Santri menyadari bahwa matematika itu penting bagi mereka terutama untuk menyiapkan diri sebagai kader ulama. Matematika dibutuhkan untuk menghadapi permasalahan dalam kehidupan sehari-hari yang berkaitan dengan peran mereka kelak setelah lulus dari pondok pesantren baik, baik peran mereka sebagai kader ulama, maupun ketika memasuki pendidikan di perguruan tinggi.

Santri masih menghadapi beberapa hambatan dan kesulitan dalam pembelajaran matematika di kelas. Beberapa hambatan dan kesulitan yang dihadapi santri dalam proses pembelajaran matematika menyebabkan mereka malas belajar matematika dan akhirnya kurang serius ketika belajar matematika, baik ketika di kelas ataupun mengerjakan tugas matematika di asrama.

Adapun motivasi guru dalam mengajarkan matematika di Pondok Pesantren, yaitu 1) Ingin menjadikan pendidikan matematika yang didapat anak santri setara/ sama dengan pendidikan matematika yang didapat oleh siswa di luar pesantren, dengan harapan selain santri mampu dalam pelajaran agama juga dalam pendidikan sains; 2) Matematika mempunyai sifat koneksi dimana matematika bisa dihubungkan dengan bidang studi apapun termasuk dengan bidang keagamaan; 3) Membantu Pondok Pesantren; 4) Berbakti kepada agama dan masyarakat.

Guru memiliki motivasi yang tinggi dalam mengajarkan matematika, namun mereka 
menghadapi kesulitan dalam mengajarkan matematika karena jam pelajaran yang lebih sedikit dibanding dengan jam pelajaran matematika di sekolah non pesantren muadalah, sedangkan kurikulum matematika sama dengan sekolah lain Sekolah Menengah Atas (SMA) atau Madrasah Aliyah (MA). Jam pelajaran matematika di beberapa pondok pesantren yang diobservasi adalah 2 sampai 3 jam pelajaran. Adapun buku yang digunakan juga sama dengan SMA atau buku yang disusun Pondok Modern Gontor yang materi juga sama dengan di SMA dan MA. Kemudian para guru juga masih kesulitan menentukan metode pembelajaran matematika yang cocok untuk para santri, yang mampu mengaitkan materi matematika dengan kebutuhan mereka sebagai santri dan yang dapat meningkatkan motivasi santri dalam belajar matematika.

Menurut Suryadi (2019) terdapat tiga jenis hambatan belajar ontogenic, yaitu bersifat psikologis, instrumental, dan konseptual. Hambatan ontogenik psikologis yang dihadapi santri adalah motivasi dan ketertarikan terhadap matematika yang menurun selama proses pembelajaran matematika walaupun sebenarnya pada awalnya mereka menyadari bahwa matematika itu penting bagi mereka terutama untuk menyiapkan diri sebagai kader ulama. Menurut mereka, matematika dibutuhkan untuk menghadapi permasalahan dalam kehidupan sehari-hari yang berkaitan dengan peran mereka kelak setelah lulus dari pondok pesantren baik, baik peran mereka sebagai kader ulama, maupun ketika memasuki pendidikan di perguruan tinggi.

Hambatan ontogenik psikologis ini disebabkan oleh hambatan ontogenik instrumental misalnya menurut meraka, materi dalam matematika sulit dipahami, rumus matematika rumit dan sulit dihafalkan, kurang percaya diri dalam menyelesasikan soal matematika, dan kesulitan dalam mengerjakan soal yang tidak sesuai contoh. Hambatan ontogenik psikologis ini disebabkan oleh hambatan ontogenik konseptual misalnya menurut mereka pembelajaran matematika membosankan karena terlalu serius dan materi matematika terlalu banyak angka dan huruf. Berbagai hambatan ini membuat motivasi dan ketertarikan mereka terhadap pembelajaran matematika menurun.

Hambatan didaktis disebabkan urutan dan tahapan kurikulum termasuk penyajiannya di kelas (Suryadi, 2019) dan menurut Conru (2002) Hambatan didactical yang terjadi karena sifat pengajaran dan guru. Kurikulum matematika di beberapa pondok pesantren, berdasarkan observasi yang telah dilakukan sama dengan kurikulum matematika Sekolah Menengah Atas (SMA) dan kurikulum Madrasah Aliyah (MA), padahal jam pembelajaran matematika di pondok pesantren lebih sedikit dibandingkan jam pelajaran matematika di SMA dan MA. Hal ini menjadi salah satu hambatan dalam proses pembelajaran matematika di pondok pesantren sebagaimana yang diungkapkan oleh santri bahwa waktu pembelajaran matematika kurang sedangkan materinya banyak.

Hambatan tersebut juga berdampak kepada penyajian dan pengajaran matematika oleh guru di kelas karena mengejar materi yang banyak sedangkan jam pelajaran yang terbatas jadi tidak bisa memaksimalkan proses pembelajaran matematika dan mengakomodir peningkatan kemampuan santri yang terkait dengan kebutuhan mereka sebagai kader ulama, termasuk dalam meningkatkan kemampuan penalaran analogis dan generalisasi santri. Padahal berdasarkan hasil Balitbang Kemenag RI (2017) mengungkapkan bahwa standar isi mata pelajaran pendidikan umum (termasuk matematika) bagi pondok pesantren direkomendasikan untuk berbeda dengan standar isi satuan lainnya.

Keterbatasan konteks dapat memunculkan hambatan epistemological (Suryadi, 2019). Hambatan epistemologis dalam pembelajaran matematika di pondok pesantren terkait juga dengan hambatan didaktis, yaitu kurikulum dan penyajian guru yang memunculkan keterbatasaan konteks pada proses 
pembelajaran matematika. Keterbatasan konteks ini terkait buku matematika yang digunakan oleh guru sama dengan buku matematika yang digunakan di SMA dan MA, walaupun misalnya ada yang menggunakan buku yang diterbitkan oleh salah satu pesantren, namun isinya sama dengan buku yang digunakan di SMA dan MA, walaupun lebih sederhana.

Keterbatasan konteks ini maksudnya proses pembelajaran matematika di pondok pesantren masih menggunakan konteks yang sama dengan proses pembelajaran matematika di SMA dan MA, padahal berdasarkan SK Direktorat Pendidikan Diniyah dan Pondok Pesantren Kementerian Agama (2015) pembelajaran matematika di pondok pesantren hendaknya dimulai dengan pengenalan masalah yang sesuai dengan situasi (muqtadhal hal) Pondok Pesantren setempat, misalnya ketika proses pembelajaran konsep aritmatika dan aljabar dikaitkan dengan memecahkan masalah kehidupan sehari-hari dan masalah-masalah perhitungan dalam masalah fiqih zakat dan fiqih mawarits atau juga misalya ketika proses pembelajaran aturan dalam logika matematika yang dikaitkan dengan masalah pengambilan keputusan dan argumentasi sehingga lebih mampu menerapkannya pada disiplin ilmu manthiq.

Beberapa rekomendasi untuk meminimalisir hambatan belajar yang dihadapi santri beberapa hal berikut.

1. Untuk menumbuhkan motivasi dan ketertarikan terhadap matematika, didesain di awal pembelajaran dengan pembacaan ayat suci Al-Qur'an dan Hadits yang berkaitan dengan materi pembelajaran matematika yang akan diajarkan dan pemberian gambaran tentang manfaat mempelajari materi yang akan dipelajari dalam kehidupan sehari-hari terutama manfaat bagi santri menjadi kader ulama. Hal ini dilakukan juga berdasarkan hasil penelitian Saksono (2015) yang menggungkapkan bahwa pembelajaran matematika dengan menambahkan ayatayat pilihan dalam soal dapat meningkatkan hasil belajar peserta didik. Pembelajaran matematika yang disesuaikan dengan lingkungan pondok pesantren yang sangat kental dengan dunia keislaman diharapkan dapat membuat mata pelajaran matematika dapat menambah motivasi belajar matematika (Hasanah, 2014).

2. Proses pembelajaran di kelas didesain dengan pembelajaran penemuan terbimbing untuk menghindari hambatan didaktis karena menurut Brown (2008) hambatanhambatan didaktis dapat dihindari melalui pengembangan pendekatan pembelajaran alternatif. Materi dan tujuan pembelajaran juga dikaitkan dengan pengetahuan Agama Islam, misalnya materi pembelajaran dikaitkan dengan fiqih zakat atau fiqih mawarit. Misalnya materi Barisan dan Deret dikaitkan dengan Zakat Hewan Ternak atau materi Aljabar dengan Mawarits.

3. Pembelajaran matematika didesain dimulai dengan pengenalan masalah yang sesuai dengan situasi (muqtadhal hal) pondok pesantren setempat, misalnya ketika proses pembelajaran konsep aritmatika dan aljabar dikaitkan dengan memecahkan masalah kehidupan sehari-hari dan masalahmasalah perhitungan dalam masalah fiqih zakat dan fiqih mawarits atau juga misalya ketika proses pembelajaran aturan dalam logika matematika yang dikaitkan dengan masalah pengambilan keputusan dan argumentasi sehingga lebih mampu menerapkannya pada disiplin ilmu manthiq. Hal ini dilakukan untuk menghindari hambatan epistemologis karena menurut Calvaho et al (2004) hambatan epistemologis terkait dengan konsepsi anakanak yang diperoleh dari kehidupan seharihari mereka. Lembar kerja santri didesain dengan konteks fiqih zakat atau fiqih mawarits. 


\section{KESIMPULAN}

Terdapat beberapa hambatan belajar yang dialami santri dalam pembelajaran matematika di pondok pesantren, yaitu sebagai berikut.

1. Hambatan ontogenik yang dialami santri berasal hambatan ontogenik instrumental dan hambatan ontogenik konseptual sehingga berpengaruh terhadap hambatan ontogenik psikologis, yaitu membuat motivasi dan ketertarikan santri terhadap pembelajaran matematika menjadi menurun.

2. Hambatan didaktik terjadi karena kurikulum matematika yang digunakan sama dengan kurikulum matematika di SMA atau MA sehingga berpengaruh terhadap penyajian dan pengajaran matematika oleh guru di kelas karena mengejar materi yang banyak sedangkan jam pelajaran yang terbatas jadi tidak dapat memaksimalkan proses pembelajaran matematika dan mengakomodir peningkatan kemampuan santri yang terkait dengan kebutuhan mereka sebagai kader ulama, misalnya dalam meningkatkan kemampuan penalaran analogis dan generalisasi santri.

3. Hambatan epistemologis terjadi karena proses pembelajaran terpaku kepada buku teks SMA atau MA sehingga konteks pembelajaran sama dengan pembelajaran matematika di SMA atau MA dan tidak dikaitkan dengan konteks pengetahuan agama Islam atau sesuai dengan situasi (muqtadhal hal) pondok pesantren setempat.

4. Beberapa rekomendasi untuk meminimalisir hambatan belajar yang dihadapi santri beberapa hal berikut: a) didesain di awal pembelajaran dengan pembacaan ayat suci Al-Qur'an dan Hadits yang berkaitan dengan materi pembelajaran matematika yang akan diajarkan dan pemberian gambaran tentang manfaat mempelajari materi yang akan dipelajari dalam kehidupan sehari-hari terutama manfaat bagi santri menjadi kader ulama; b) Materi dan tujuan pembelajaran juga dikaitkan dengan pengetahuan Agama Islam; dan c) Pembelajaran matematika didesain dimulai dengan pengenalan masalah yang sesuai dengan situasi (muqtadhal hal) pondok pesantren setempat.

\section{REFERENSI}

Al-Syatibi, \& Ishaq, A. (2003). al-Muwafaqat fi Ushul al-Syari'ah. Vol. II.

Arifin, B. (2015). Fatwa Dan Demokrasi: Studi Terhadap Fatwa Majelis Ulama Indonesia (MUI). At-Tahdzib: Jurnal Studi Islam dan Muamalah, 3(1), 11-34.

Balitbang, K. (2017). Retrieved from https://balitbangdiklat.kemenag.go.id/ posting/read/1787-PenyelenggaraanPendidikan-Muadalah-di-PondokPesantren.

Brown, S. A. (2008). Exploring Epistemological Obstacles to The Development Of Mathematics Induction. Roc of the 11th for Research on Undergraduates Mathematics Education.

Carvalho, G. S., Silva, R., Lima, N., Coquet, E., \& Clément, P. (2004). Portuguese Primary School Children's Conceptions about Digestion: Identification of Learning Obstacles. International Journal of Science Education, 26(9), 1111-1130.

Cornu, B. (2002). Limits. In Advanced mathematical thinking (pp. 153-166): Kluwer Academic Publishers.

Direktorat PD Pontren. (2015). Kerangka Dasar dan Struktur Kurikulum Satuan Pendidikan Mu'adalah. Jakarta: Direktorat Jenderal Pendidikan Islam Kementerian Agama Republik Indonesia 
Dhofier, Z. (1982). Tradisi pesantren: Studi tentang pandangan hidup kyai: Lembaga Penelitian, Pendidikan, dan Penerangan Ekonomi dan Sosial.

Eksan, M. (2000). Kiai Kelana: Biografi Kiai Muchith Muzadi: PT LKiS Pelangi Aksara.

Hallaq, W. B. (1985). The logic of legal reasoning in religious and non-religious cultures: The case of Islamic law and the common law (Vol. 34): Clev. St. L. Rev.

Hasanah, S. I. (2014). Sumber Belajar Matematika dari Lingkungan Alam Sekitar Berbasis Pondok Pesantren. INTERAKSI: Jurnal Kependidikan, 9(1).

Hiebert, J. (1997). Making sense: Teaching and learning mathematics with understanding: ERIC.

Hsubky, B. (1995). Dilema ulama dalam perubahan zaman: Gema Insani Press.

UNDANG-UNDANG REPUBLIK INDONESIA NOMOR 18 TAHUN 2019 TENTANG PESANTREN, (2019).

Kahmad, D. (2006). Sosiologi Agama, cet IV. Bandung: Remadja Rosdakarya.

Kesgin, S. (2011). A Critical Analysis Of The Schacht's Argument And Contemporary Debates On Legal Reasoning Throughout The History Of Islamic Jurisprudence. The Journal of International Social Research, Cilt(19).

Liu, S. L. (2008). Student interaction experiences in distance learning courses: A phenomenological study. Online Journal of Distance Learning Administration, 11(1).

Madjid, N. (1997). Bilik-Bilik Pesantren Sebuah Potret Perjalanan. Jakarta: Paramadina.

Mastuhu. (1994). Dinamika sistem pendidikan pesantren: suatu kajian tentang unsur dan nilai sistem pendidikan pesantren: INIS.

Nasir, M. R., \& Abdushomad, M. A. (2005). Mencari Tipologi Format Pendidikan Ideal: Pondok Pesantren di Tengah Arus Perubahan: Pustaka Pelajar.

Nisa, K. (2014). Pengembangan Perangkat Pembelajaran Matematika Yang Mengintegrasikan Integral Matematika Dan Hukum Waris Dengan Model Integrated Learning Berbasis Masalah. UIN Sunan Ampel Surabaya,

Peraturan Menteri Agama tahun 2014 tentang Satuan Pendidikan Mu'adalah di Pondok Pesantren, 18 C.F.R. (2014).

Pontren, D. P. (2009). Pedoman Penyelenggaraan Pondok Pesantren Mu'adalah. In: Jakarta: Direktorat Pendidikan Diniyah dan Pondok Pesantren.

Saksono, D. Y. (2015). Pengembangan Pembelajaran Matematika Berbasis Al Qur'an Di Sekolah Menengah Pertama Muhammadiyah 9 Gemuh Pondok Pesantren Darul Arqam 4 Kendal. Disertasi Universitas Muhammadiyah Surakarta.

Suryadi, D. (2019). Landasan Filosofis Penelitian Desain Didaktis (DDR): Pusat Pengembangan DDR Indonesia.

Tamawa, M. M. (1972). al-Ijtihad wa Madza Hajatina ilaihi fit Hadzin al-'Ashr. Mesir: Dar al-Kutub al-Haditsah.

Usman, M. I. (2013). Pesantren Sebagai Lembaga Pendidikan Islam (Sejarah Lahir, Sistem Pendidikan, Dan Perkembangannya Masa Kini). Jurnal al-Hikmah, 14(1), 127-146.

Yusnita, E. (2011). Pembelajaran Kontekstual berlatar pondok pesantren pada materi garis dan sudut di kelas VII MTS. Paper presented at the Prosiding Seminar Nasional Matematika Dan Pendidikan Matematika UNY. 
Zaidan, A. K. (1990). Al-Wajiz fi Ushul al-Fikih. Aman Yordania: Muassasah al-Risalah. 